669.018 .8

\title{
化学装置材料の最近の動 向"
}

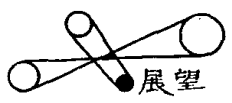

北村 義，治**

\section{1. まえがき}

各種化学工業の発展は近年特に著しいがこれには 装置を構成する材料の進歩，発達が非常に重要な役割 りを果たしている．近代の化学工業においては，取扱 ら原料および製品の多様化，操業の連続化，操作条件 の高温・高圧化，さらに，装固の大形化などが急速に 進展し，装置材料のおか和環境は過酷化の一途をた どっている．それに伴ってこれら環境条件に耐えうる 適正な装置材料が強く望まれている。 また一方，新し い装置材料の出現によって，これまで工業的に不可能 と考えられていた新プロセス，新製品の開発が可能と なったものも少なくない.

化学装置材料として具備す心゙き要件は, 物理的, 機 械的性質，加工性および経済性などに加えて耐食性が 最も重要な因子である、そこでこの耐食性に注目して 鉄鋼，ステンレス鋼，ニッケル合金，滈けい素鋳鉄お よびニッケルけい素合金, 銅合金, アルミニウム合 金, 鉛合金, 特殊金属打よび有機材料の順に, 化学装 置材料としての各材料の最近の進歩および研究の動向 についてその概要を述べる.

\section{2. 鉄鋼}

鉄鋼の耐食材料としての位置はそれほど大きなもの ではない，しかし，機械的性質にすぐれしかも安価で あることから大気，水，ガス，石油などの環境に対し ての基本的構造材料として広く利用されている。最 近，鉄鋼のこれらのすぐれた特性に加えて，耐食性を 向上させるための研究がいろいろの方面でなされ，ま た実用材料として市販されてきている。これらは，低 合金鋼による耐酸性, 耐海水性の向上, 高力鋼の耐候 性，硫化水素割れ耐性の向上などに分けられる。

近年，燃料が石油系中心に変化してきていることか ら，いおらの燃焼により生成する亜硫酸および硫酸が 鉄銅材料の腐食に対して考慮すべき重要な環境因子と なってきた。また，工業地帯で泠却水として利用でき る水の質が低下してきていることと，量的不足を補な

* 原稿受付 昭和 42 年 8 月 21 日.

** 正圆, 味の素会社中央研究所 (小川崎扩鉿木町 2964).
うために，污染海水なども大量に使用しなければなら なくなり，このため鉄鋼材料の耐食性の向上が要求さ れてきている.

燃焼ガス中の亜硫酸, 硫酸を考慮して, ボイラなど の構造材料の鉄鋼の耐酸性を向上させる試みが多くな されている(1) (3)．一般に，鉄鋼の耐食性を向上させ る元素として $\mathrm{Cu}$ が知られている(4). 因 1 に炭素鋼に 銅を添加した場合の室温 $42 \%$ 硫酸に対寸る耐食性へ の効果を示す.したがって，この目的でも添加元素と して Cuをべースにしているものが多い，たとえば 低濃度の硫酸に対して， Cu, S の共存が耐食性を向上 させ，また両者に $\mathrm{Sn}, \mathrm{Pb}, \mathrm{As}, \mathrm{Sb}$ などが加わるとさ らによくなる(2)(s)，また，炭素鋼に対する $\mathrm{Si}, \mathrm{Cu}, \mathrm{Ni}$ ， $\mathrm{Mo}, \mathrm{Sn}$ などの添加は硫酸による腐食に対して効果が あり，含 $\mathrm{Cu}$ 鋼では $\mathrm{Sn}, \mathrm{As}$ の添加が有效であること が報告されている(2).ささらに他の研究では，含 $\mathrm{Cu}$ 鋼 に対して Sb, Se, As, Si の添加が $40 \%$ 硫酸中の腐食 速度を小さくすることが明らかにされている(3).

これらはいずれも水素発生形の腐食であるので，耐 食性恃水素過電圧との関連に抢いて説明されるが，工 業用水，海水などによる腐食は酸素還元形となるの で，耐海水鋼などの耐食性はおもに表面に生成する防 食性被膜によるものである。

とくに, $\mathrm{Cu}, \mathrm{Cr}, \mathrm{Al}, \mathrm{Ti}$ (または $\mathrm{Nb}, \mathrm{Zr}$ ) を含有 する鋼は耐海水腐食性が炭素鋼の約 2 倍になり ${ }^{(6)}$, ま た, $\mathrm{Cu}, \mathrm{Ni}$ を含む Mariner 鋼は $2 \sim 3$ 倍の耐食性を 示すことが報告されている(7).

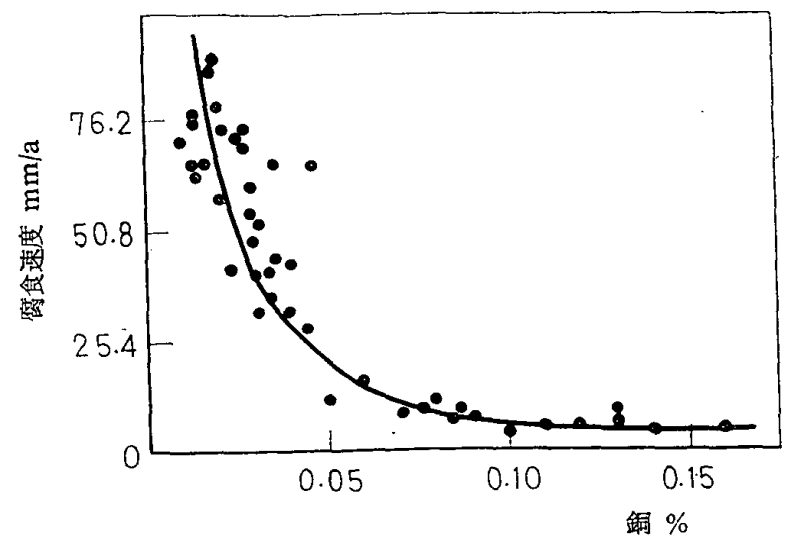

図 $142 \%$ 硫酸（室温）に対する炭素鈵の 酎食性行及代す銅の影響(4) 
近年，高力鋼の発達はめざましいものがある(8)が， これと同時に，一時，硫化物による割れ事故が多発し 問題となった.これに関してはくわしい解説が多くな されており(9) (11)，また機構その他に関する詳細な研 究も多い(12) (18).

図 2 に高力鋼の硫化水素による応力腐食割れに及ぼ す濃度と応力との関係を示す。

この原因は，硫化水素と $\mathrm{Fe}$ の反応によって生ずる 水素によるものと解釈されており，種々の対策が考え られている。材料側からは， $\mathrm{Ni}$ 含有鋼の割れ感受性 が高いことが判明しており， Ni を含まない高力鋼が 提案されている(8)(12)(16)(19)(20). また硫化水素と Feよ り発生する原子水素の還元の促進が鋼中への水素の侵 入を防止することに着目し，カソードとなる貴元素を 微量入れて，硫化物腐食割れを防止する鋼が開発され ている(21).

最近，耐候性高力鋼の発展はめざましく，多くの鋼 種が開発され，屋外構造用鋼として広く用いられて きた(22). これらは添加元素として $\mathrm{Cu}, \mathrm{P}$ を基本にし, $\mathrm{Cr}, \mathrm{Ni}, \mathrm{Ti}, \mathrm{Zr}$ などとの複合効果により，表面生成被 膜の密着性が増大し, 大気中での腐食速度を小さくし ている。これらには, $\mathrm{Cu}-\mathrm{P}-\mathrm{Ti}$ 系 ${ }^{(23)}, \mathrm{Cu}-\mathrm{P}-\mathrm{Cr}-\mathrm{N}$ 系 ${ }^{(24)}, \mathrm{Cu}-\mathrm{P}-\mathrm{Cr}-\mathrm{Mo}$ 系(25), $\mathrm{Cu}-\mathrm{P}-\mathrm{Cr}-\mathrm{Zr}$ 系(26) など があり，それぞれすぐれた酎候性を示している.

化学装置用としてさらに鹰食作用のある環境に用い る場合には，装置・機器を構成している鉄鎠基材にめ っき,クラッディング, 溶射 (金属, 無機および有機 材料)，ライニング（金属，無機扝よび有機材料），コ 一チングおよび塗装などにより被覆し, 環境と鉄鋼基 材とをしや断する方法が行なわれている.

\section{3. ステンレス鋼}

ステンレス鋼は現在用いられている耐食材料の多く

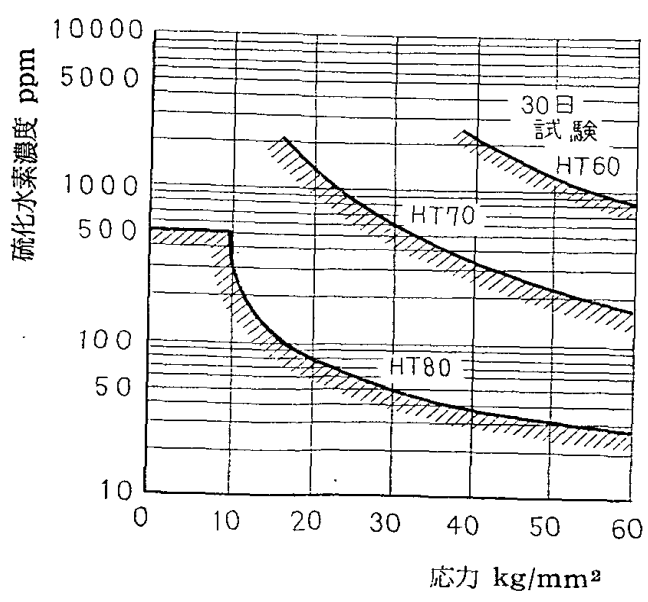

図 2 高力鋼の割れ発生に対する付加応力と 硫化水素濃度の限界值との関俰(15)
の部分を占め, 使用される環境も非常に広く，また量 的にも多大である. 化学工業, 原子力工業関係などの 著しい発達に伴い，ステンレス鋼の接する環境がます ます多様化，過酷化し，これに応じて新しい鋼種の開 発が進められている。

ステンレス鋼の優秀な耐食性は，その表面に生成す る Passive film による.したがって，その腐食形態 は，被膜が均一に溶解する全面腐食と部分的に破れる 局部腐食に分けられ，後者には孔食，応力腐食割れ， 粒界腐食などがある.つぎに, 各腐食形態ごとに最近 の研究動向执よび新しい耐食鋼種につき述べる。

$3 \cdot 1$ 均一腐食 非酸化性酸に対するステンレス鋼 の耐食性を向上させる試みが多くなされている.とく に, 耐硫酸性の向上には $\mathrm{Ni}$ 含量の增加と $\mathrm{Cu}$ の添加, 耐塩酸性には Mo が有効なことは古くから知られてお り，種々の鋼種が開発されている，耐硫酸鋼としての $19 \mathrm{Cr}-29 \mathrm{Ni}-2.5 \mathrm{Mo}-3 \mathrm{Cu}$ は有名であるが，この Ni を 33〜35 とした鋼種が開発され(27), さらに V, Ti ${ }^{(28)}$, $\mathrm{Sn}{ }^{(29)}$ を添加し，加工性の向上がはかられている。こ れによって，高温硫酸に対する耐食性が大幅に向上す る.しかしここれら鋼種には $60 \sim 70 \%$ 硫酸に対する 耐食性がよくないといら共通の弱点があるが，これに 対して Cr の割合を增してこれを改善する試みがなさ れている(30).

$18 \mathrm{C}$ - $8 \mathrm{Ni}$ 系鋼の耐食性を向上させるために種々の 元桑の添加が試みられている.これらには局部カソー ドとなる Pt などの貴元素を添加するむの (31)(32)，Sn, $\mathrm{Cu}$ などを添加するもの(33)(34), Co の添加(35) などがあ り，これによって耐酸性が著しく改善される. 図 3 に 貴元素添加の硫酸に対する耐食性への影響を示す.

マルテンサイト系, フェライト系ステンレス鋼につ いても耐食性の改善がなされている１7Cr 鋼に対す

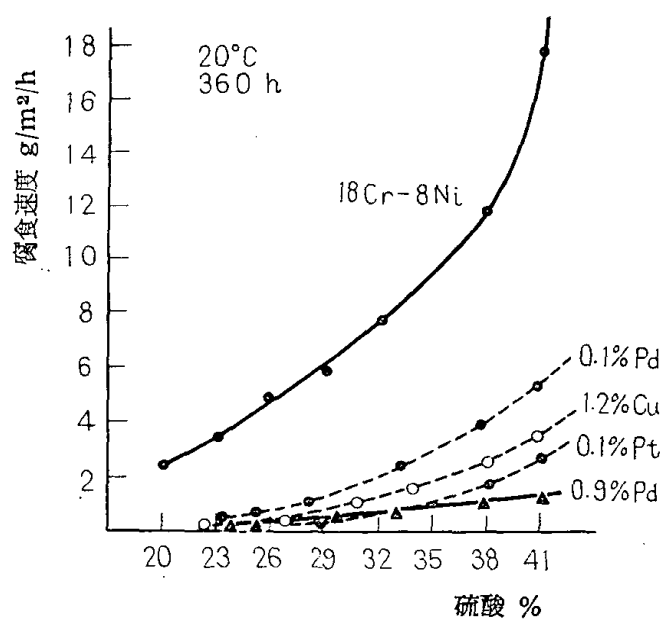

图 3 18Cr-8Ni ステンレス鋼の耐食性に 及ぼす添加元素の影響(31) 
る $\mathrm{Mo}, \mathrm{Si}, \mathrm{Cu}$ の添加により Passive になりやすく， また被膜も強固になり ${ }^{(36)}, 25 \mathrm{Cr}$ 鋼に $\mathrm{Ni}, \mathrm{Mo}$ を加え ると耐食性が向上し(37)(38)，また $20 〜 30 \mathrm{Cr}$ 鋼を 470 〜 $530^{\circ} \mathrm{C}$ で熱処理することにより，有機酸に対する耐 食性が向上する(39)ことが報告されている。

$3 \cdot 2$ 孔食 オーステナイト系ステンレス鋼の耐 孔食性は，Moや Si の添加で上昇することが古くよ り知られ，5\% Mo 鋼が耐孔食鋼として賞用されてき た.このような有効添加元素はほかに $5 \% \mathrm{~V}, 1 \% \mathrm{Re}$ などが報告されている(40). 図 4 にこれら元素の効果を 示す. $\mathrm{Ni}, \mathrm{Mo}$ を含むフェライト系高 $\mathrm{Cr}$ 鋼も優秀な 耐孔食性を有することが報告されている(41).この耐孔 食性は $5 \% \mathrm{Mo}$ 鋼よりもすぐれている.

$3 \cdot 3$ 応力腐食割扎 ステンレス鋼の耐応力腐食割 れにおよぼす合金組成元素, 添加元素执よび加工(42)の 影響に関する研究は，数多くなされている.

まず， $\mathrm{Ni}$ 含有量を增加すると著しく感受性を下げ ることは古くから明らかにされ，高 $\mathrm{Ni}$ ステンレス鋼 (Ni 25 40\%) が多く開発され使用されてきた. ま た，添加元素抢よび不純物に關しては，感受性を下げ るものとしてC, Si，それ家高めるものとしてN, P, As， $\mathrm{Sb}, \mathrm{Al}$ などが知られている(43)(44). また, $\mathrm{Mo}, \mathrm{Cu}$ \& 粒内割れ感受性を高めていると考えられている(45)(46). さらに，オーステナイト系ステンレス鋼は高温か性ア ルカリ環境でも応力腐食割れを生ずるが，Moがこの 感受性を高めていることも考えられ(47)，Moを含ま ない高 $\mathrm{Ni}$ ステンレス鋼が試作されている。

オーステナイト系以外では，高 $\mathrm{Cr}-\mathrm{Ni}$ 鋼(48)， PH 鋼(49)などが応力腐食割れに対して良好な耐性を有し ていることが報じられている.

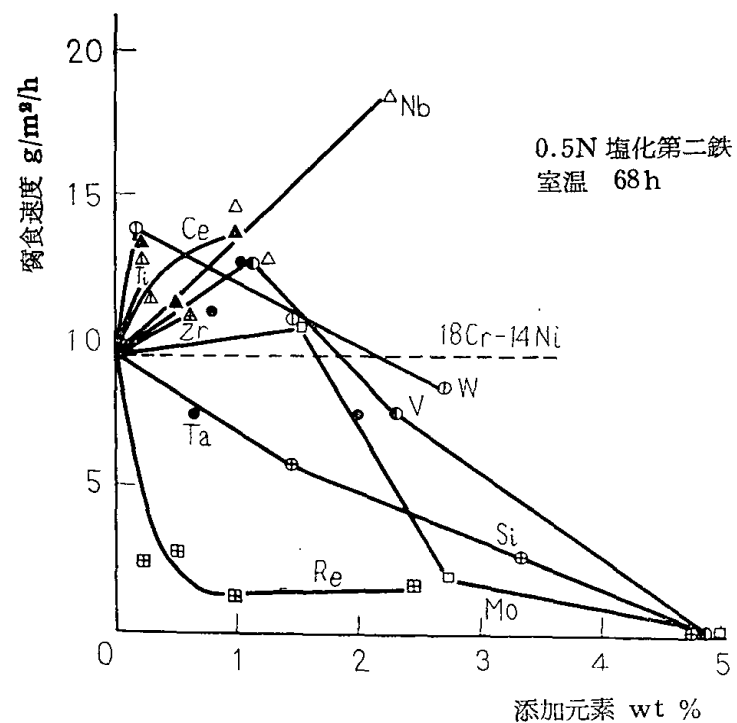

図 4 18Cr-14Ni ステンレス銅の耐孔食性に 及ぼす添加元素の影響(40)
3.4 粒界㦄食 粒界腐食に対しては含有 C量を少 なくした低 $\mathrm{C}$ 鋼種と， $\mathrm{Ti} ， \mathrm{Nb}$ などにり Cを安定化 した鋼種により対策は一応完成されているといえる.

しかし， $\mathrm{Ti}, \mathrm{Nb}$ など炭化物生成安定化元素の添加， 含有 $\mathrm{C}$ 量の減少, 高温加熱・急冷による溶体化処理な どをほどこした材料でも粒界腐食の発生する可能性は あり，結晶粒界に何ら析出物がなくても発生すること が報告されている(50). 引続き研究されなければならな い分野である.

\section{4. ニッケル合金}

$\mathrm{Ni}$ ベースの耐食性合金は， $\mathrm{Ni}-\mathrm{Cu}$ (モネルなど)， $\mathrm{Ni}-\mathrm{Cr}-\mathrm{Fe}$ (インコネル 600 など), Ni-Mo (ハステロ

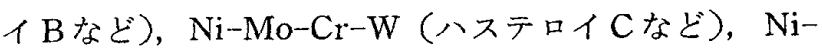
$\mathrm{Cr}-\mathrm{Fe}-\mathrm{Mo}$ (ハステロイ $\mathrm{F}$ など)， Ni-Cr-Fe-Mo-Cu (イリウム，ハステロイ G， インコロイ 825 など) の 各系に分類される(51). これらは，いずれも熱力学的に かなり安定な Ni をベースに還元性環境に対し耐性の ある $\mathrm{Cu}, \mathrm{Mo}$ ，また酸化性環境で Passive になりやす く，強固な被膜を形成する $\mathrm{Cr}$ などを合金成分とする もので，耐食合金中，最もすぐれた性能を示し，超合 金とも称せられる.しかし，機械加工性，価格などの 面で難点も多く，性能がすぐれている割合には用途が 限られている。これら合金の特徴, 耐食性などについ てはすでに系統的解説がなされている(51).

$\mathrm{Ni}-\mathrm{Cu}$ 系は， $\mathrm{Ni}$ および $\mathrm{Cu}$ がそれぞれの熱力学的 性質より耐酸化性，還元性を相補ってよい耐食性を示 す。また，同時に含まれる Fe がとくに高温水中など での耐食被膜の形成に有効である(52).

$\mathrm{Ni}-\mathrm{Cr}-\mathrm{Fe}$ 系は， $\mathrm{Cr}$ を含むことにより耐酸化性がよ い、しかし，高 Ni 合金にもかかわらず，高温高圧水 中で応力がかかると粒界割れをおこす(53).この傾向は 高 $\mathrm{Ni}$ オーステナイト合金に共通の現象で，Ni-Mo 系 にも見られる(54).

Ni-Mo 系は Mo を多量に含むため耐塩酸性が良好 で，耐塩酸合金として知られている，耐塩酸性は Fe

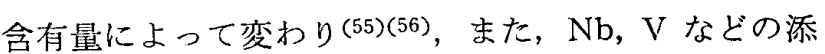
加は耐食性，機悈加工性によい影響を与える(57)。 た, $\mathrm{Cu}, \mathrm{W}$ および微量の Ti の添加によって溶接性, 耐食性，延性などが向上する(58).

$\mathrm{Ni}-\mathrm{Mo}-\mathrm{Cr}-\mathrm{W}$ 系は， $\mathrm{Cr}$ を比較的多量に含むため耐 酸化性が著しく向上する。この合金は熱影響に対しか なり鋭敏で, 熱処理温度, 時間, 冷却速度などによ って, 種々の複雑な析出物支生じ粒界腐食が発生す る(59)。この系の合金の熱処理と金属組織と，腐食速度 の間には図 5 の関係がある.これを防止するために 
は，高温からの急冷がよい(60). またここの系は塩化物 による孔食に対してもオーステナイト系ステンレス鎆 よりはるかによい耐性を示すが，この系のCr 增し， $\mathrm{Ni}, \mathrm{Mo}$ を減らし，低価格にて耐孔食性の目的を達成 する試みがなされている(61).

$\mathrm{Ni}-\mathrm{Cr}-\mathrm{Fe}$-Mo 系は, $\mathrm{Ni}-\mathrm{Mo}-\mathrm{Cr}$ 系より $\mathrm{Cr}$ を増し， Mo を減じているので，酸化性環境に対する耐食性が 向上している，応力腐食割れ，孔食などに対する耐性 もよい.

$\mathrm{Ni}-\mathrm{Cr}-\mathrm{Fe}-\mathrm{Mo}-\mathrm{Cu}$ 系は，さらに $\mathrm{Cu}$ が含まれるの で耐硫酸性が向上する。 また粒界腐食に耐性のあるC 安定化形もある(62)。

\section{5. 高けい素鉡鉄およびニッケルけい素合金}

高 $\mathrm{Si}-\mathrm{Fe}$ 合金は古くから耐酸鋳鉄としてポンプな どに重要な役割をはたしてきた，ただしこの系の機械 加工性はきわめて悪く，用途が限られる欠点がある.ま た耐食性を向上させるための合金元素添加については Mo による耐塩酸性の向上が以前よりなされている が,さらにCrを加えることにより酸化性環境に対する 耐食性をも向上させる試みがなされている(63)(64).

$\mathrm{Ni}-\mathrm{Si}$ 合金は，これに少量の $\mathrm{Cu}$ を加えた系が知ら れている. 耐食性, 機械加工性も Fe-Si 系よりすぐれ ているが，Ti の添加によりさらに延性が増大するこ とが知られている(65). しかし， Ni を多量に含むため 高価である.

$\mathrm{Ni}-\mathrm{Si}$ 系の $\mathrm{Ni}$ の相当分を $\mathrm{Fe}$ で置き換えた合金は 耐硫酸，塩酸性がよく(66)，これにさらに Cu を多量加 えると耐酸性が 10〜20 倍も向上することが見出され ている(67).

\section{6. 銅 合 金}

耐食材料としての銅および銅合金は，ほとんど大部

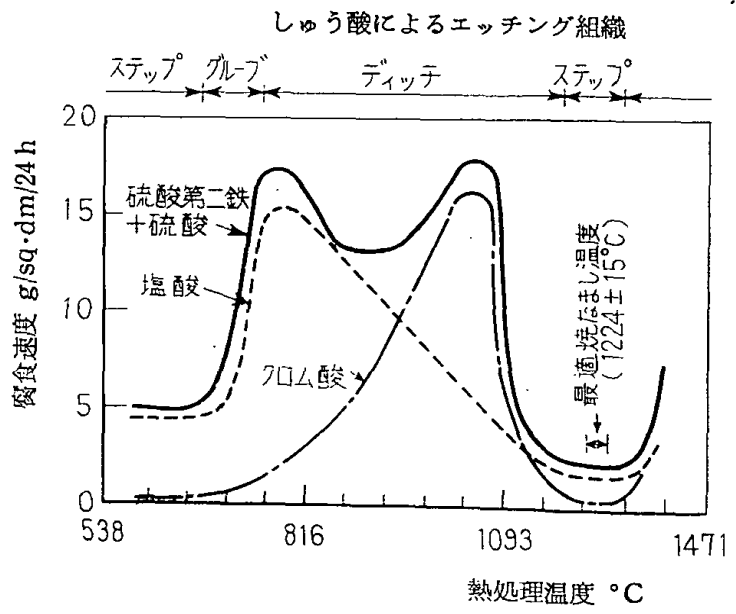

図 $5 \mathrm{Ni}-\mathrm{Cr}-\mathrm{Mo}$ 合金の熱処理，エッチ 組織と耐食狌の関係(59)
分が冷却水を扱う冷却器, 凝縮器などの熱交換部に使 用される.したがって銅合金は，海水，河水その他各 種の工業用水に対して十分な耐食性が要求される.

近年, 工業の著しい発達とともにこれら工業用水, とくに都市近郊における海水, 河水の污染がひどく, これらを使用するコンデンサなどの銅合金に激しい腐 食をおこすことが多くなった。

銅合金の海水，污染水による腐食には，均一腐食の ほかに孔食, かい食, 脱 $\mathrm{Zn}$ 腐食, 応力腐食割れなど がある.コンデンサチューブなどに使用される銅合金 は，黄銅系，青銅系およびキュプロニッケル系がおる であるが，これらはそれぞれ前記腐食形態に対し， 独特の挙動を示す.

黄銅は $70 \mathrm{Cu}-30 \mathrm{Zn}$ 系を主体に広く利用されている 材料であるが耐食的には十分でなく，とくに脱 Zn 應 食をおこしやすい欠点がある，黄銅の脱 $\mathrm{Zn}$ 腐食に関 しては古くから現在に至るまで，多くの研究がなされ ている(68). また，これに対する耐食合金の開発も数多 くなされ，添加元素として As， Sb，P などが著しい 効果を示すことがわかってきた。これらの機構につい ても, 順次明らかにされつつある(69). 一般に黄銅の耐 食性，とくに耐かい食性を改善する元素としては，Sn や $\mathrm{Al}$ があり，それぞれ $\mathrm{Sn}$ 黄銅， $\mathrm{Al}$ 黄銅として広く 使用されている。これらは污染水に対しても良好な耐 食性を示す(70)(71)。この $\mathrm{Sn}$ 黄銅に $\mathrm{Ni}$ および Fe を添 加すると耐かい食性がさらに改善され(72)，また Al 黄 銅の高温性能を向上させるために $\mathrm{Ni}, \mathrm{Be}, \mathrm{Si}, \mathrm{Mn}$ を 少量添加する方法が開発されている(73).

銅合金に多い腐食として，アンモニア性環境に㧍け る応力腐食割れがある(74). 黄銅はとくに応力腐食割れ 感受性が高いため, 多くの基礎的研究がなされてい る(75) (78). 黄銅の耐応力腐食割れの材料的改善につい ては，たとえば $\mathrm{Si}, \mathrm{Ce} の$ 添加(79)，Sn 黄銅に対する $\mathrm{Ni}, \mathrm{Fe}$ の添加 ${ }^{(72)}$, 高力黄銅に対する微量の B, Cr の 添加(80)などが試みられている.

青銅系銅合金の耐食材料も多様であり， $\mathrm{Sn}, \mathrm{Si}, \mathrm{P}$, Al の各青銅などがこれに含まれる、青銅の耐食性， とくに耐加い食性は，少量の $\mathrm{Si}, \mathrm{Al}$ を加えると向上 し(81)(82)，またSi 青銅は，応力腐食割れ耐性がすぐれ ている(74)(83). Al 青銅の耐食性は， $\mathrm{Fe}, \mathrm{Ni}, \mathrm{Mn}, \mathrm{Zn}$ などを添加することによって向上し(84)，Si の添加む 有効である(85). なお， Mn 含量の高い $\mathrm{Al}$ 青銅は耐海 水性がよくなる(86). また青銅に Sb を添加すると耐摩 耗性が向上する(87).

キュプロニッケル系の耐食性は，全般的に銅合金中 で最もすぐれていて，耐かい食(88)，耐応力鹰食割 
れ(74)(83) とも良好であり，また高温性能むすぐれてい る.この耐食性におよぼす含有 $\mathrm{Fe}$ の影響は重要で, $\mathrm{Fe}$ は被膜の密着をよくし，酎食性を向上させ(52)(89)， 同様の効果は $\mathrm{Fe}$ のほかに $\mathrm{Mn}$ にも見られる(90). ま た $\mathrm{Mg}$, Te を添加して被切削性の向上が得られる(91).

\section{7. アルミニウム合金}

耐食材料としての $\mathrm{Al}$ および $\mathrm{Al}$ 合金は，その耐食 性が古くから知られていた割合にはそれほど多いとは いえないこれは， $\mathrm{Al}$ 純金属の場合の強さが小さい こと，および強さの大きい合金は一般に耐食性が低下 すること，また，耐食材料としての利用研究が他の材 料ほど多くなされておらず，それが新たな応用を妨げ ていることなどによる。しかし，他の金属に見られな い優秀な物理的性質を有しているので，用途によっ て，今後の発達が期待される.

耐食性 $\mathrm{Al}$ 合金としては, Al-Mg 系, Al-Mg-Si 系， $\mathrm{Al}-\mathrm{Mn}$ 采, Al-Mn-Mg 系などが主である.Al 合金は， 一般に金属閒化合物を作りやすいので，化学組成と同 様に熱処理，調質が耐食性に対して重要な因子となる。 耐食材料としての $\mathrm{Al}$ 合金の利用は，構造材料とし ヶ $\mathrm{Al}-\mathrm{Mn}, \mathrm{Al}-\mathrm{Mg}, \mathrm{Al}-\mathrm{Mg}-\mathrm{Mn}, \mathrm{Al}-\mathrm{Mg}-\mathrm{Si}$ 系 ${ }^{(92)}$. タンク，容器など化学装置に $\mathrm{Al}-\mathrm{Mg}$ 系 ${ }^{(93)}$. 石油関係 の地中，海水中のパイプラインに $\mathrm{Al}-\mathrm{Mn}, \mathrm{Al}-\mathrm{Mg}-\mathrm{Si}$, Al-Mg-Mn 系など(94) (96)の耐食性, 経済性が報告さ れている，また，熱伝導性が良好なことから，石油関 係のコンデンサチューブなどにも利用されはじめてい $ろ^{(97)}$.

$\mathrm{A} 1$ 合金の耐食性に関する基礎的研究は，この腐食 形態に他の不動態化合金と同様, 孔食, 応力腐食割れ， 粒界腐食など局部腐食が多いことからこれに関連し て多数行なわれている。 $\mathrm{Al}-\mathrm{Mg}$ 系合金は，耐全面腐 食性，耐孔食性がすぐれているが， Mg 1\% 付近で最 も良好な耐食被膜を生じ(98), また, 海洋性環境におけ る実地試験からこの系のすぐれた耐候性が示されてい る(99). また，A1 合金の耐食性に対し，有効な成分と しては $\mathrm{Fe}, \mathrm{Cu}$ が知られているが， $\mathrm{Al}-\mathrm{Mg}-\mathrm{Si}$ 系でも これが確かめられている(100).

高力合金の発達に伴い，A1 合金でも応力腐食割れ， 腐食疲れなどが問題となってきている。一般に，応力 腐食割れ耐性は，Al-Mn, $\mathrm{Al}-\mathrm{Mg}, \mathrm{Al}-\mathrm{Mg}-\mathrm{Si}$ 系など はすぐれ，Al-Cu 系などが感受性が高く(101)，高力鋳 造合金では，Al-Mgより Al-Si 系のほうが耐性がよ い(102)，Al-Mg 系は他の合金より耐海水性が優秀であ るが，Al-Mgの金属間化合物が粒界に析出すると応 力腐食割れをおこし，この傾向は熱処理に大きく依存

日本機械学会誌 第71巻 第588号
する、また，少量の $\mathrm{Mn}, \mathrm{Cr}$ は，この防止に有効であ $ろ^{(103)}$.

界粒腐食は， $\mathrm{Al}-\mathrm{Cu}-\mathrm{Mg}$ 合金について見られるが， これは $\mathrm{CuAl}_{2}$ の粒界析出によるもので，冷却速度に よって感受性が変わる(104).

最近，構造材料などとして，高力 $\mathrm{Al}-\mathrm{Zn}-\mathrm{Mg}$ 系合 金の発達が著しいが，耐食性，とくに耐孔食性は他の 合金より劣る(105)。しかし，これに $\mathrm{Cr}, \mathrm{Mn}$ を添加す ると耐食性はある程度向上する(106)．なお，この系の 腐食疲れに影響する種々の因子に関する研究もなされ ている(107).

\section{8. 鉛 合 金}

$\mathrm{Pb}$ は耐硫酸金属材料として古くから利用されてき た，安価ですぐれた耐硫酸性を示すので，現在でも貴 重な存在である. $\mathrm{Pb}$ ベースの合金としては，機械的 性質を向上させる $\mathrm{Pb}-\mathrm{Sb}$ 采が古くから知られている が，耐食性は一般に低下する。

$\mathrm{Pb}$ の而硫酸性は，高温，高濃度になるとかなり低 下するが，これを防止するための種々の合金が開発さ れている、これらには，微量の Te を含むもの(108)， $\mathrm{Pb}-\mathrm{Sb}$ に Cu, Te, Ag, Ni を添加するもの(109), Si の 添加(110)微量の Se を加えるもの(111)などがある. 添加 元素の耐食性への影響を図 6 に示す.

\section{9. 特殊金属}

最近，耐食材料として著しく発展したものに $\mathrm{Ti}, \mathrm{Zr}$ ， $\mathrm{Ta}, \mathrm{Nb}$ などの特殊金属がある。これらには，それぞ れ特徵あるすぐれた耐食性を有し，また，製造法の発 達に伴い，価格が低下の傾向にある。しかし，Ti を除 いては，他の材料に比べ，まだ高価であり十分利用さ れているとはいえない。これらの耐食性は，表面に生 成する強固な Passive film による。

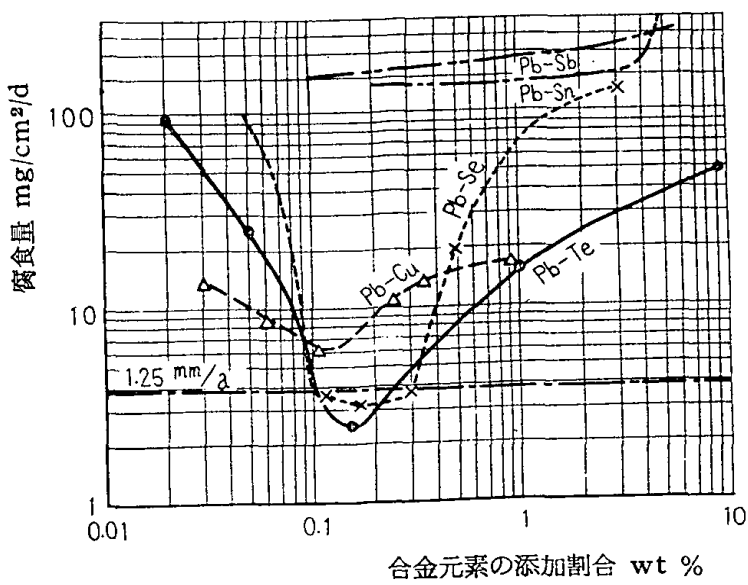

図 6 鉛の $80 \%$ 沸滕硫酸に対する耐食性に 及ぼす添加元素の影響(111) 
Ti はこれらの中では最も多く利用されており，酸 化性および塩化物環境に対し，きわめてすぐれた耐食 性を示すことが特徵である。非酸化性酸に対する耐食 性はそれほど大きくないが，局部カソードとなるよ うな Pt, Pd などを微量添加すると，かなり向上す $る^{(112) \sim(114)}$. 塩化物に対する耐食性は, 濃度が高くな ると不安定となり，孔食，すきま腐食を生ずるが(115)， Ti-Pd 合金は，これにもよい結果を示す(116).

$\mathrm{Zr}$ は酎酸性が Tiよりはるかにすぐれ，とくに耐程 酸性が優秀なため, 化学装置材料として貴重である.

また，その他の化学薬品に対しても一般にすぐれた耐 食性を示す(117)が，チタンとは対照的に酸化性塩化物 環境に弱く，激しい孔食を抗こす，また，Zr は Ti と ともに, 一般に水溶液中で応力腐食割れ感受性がない が，低級アルコール中に，塩酸，硫酸などが混在する と割れが発生する(118)．なお， Zr は原子炉材料として 多く用いられ，種々の合金が開発されているが，詳細 は省略する.

Taは, これら特殊金属中で最も安定であり, Ptに 近いすぐれた耐食性を示す。ただし，アルカリ環境に 弱い欠点がある，Taの耐食性については，すでに多 くの解説がなされている(119) (121). 牛た，水素の発生 する状態ではぜい化をおこすことが知られているが, これを防止するために，Pt，Pd など貴金属を微量添 加するとよい(122).

$\mathrm{Nb}$ の耐食性は Ta と似ているが，Taよりは多少劣 る(123). しかし，Ta 上り比重は小さく，体積当たり の価格は低いので，環境によっては有利である(124). $\mathrm{Nb}$ ベースの合金としては， Nb-V 系があり，過熱蒸 気中で良好な耐食性を示す(125).

\section{0. 有機材料}

新しい高分子物の合成は，広く試みられているが， 実用になっている高分子物の種類はここ数年間ほとん

表 1 耐食有機材料

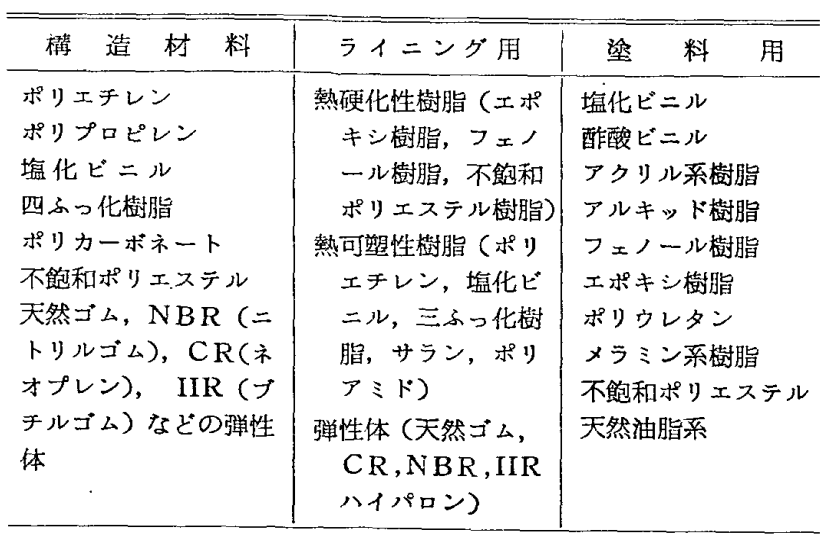

ぼふえていない，しかし，現在使用されている高分子 物の改質については種々試みられている．高分子物の 改質の代表的なものとしては，重合または縮合方法の 改良による分子内の単量体の配列方法の変更, 高分子 物の後処理，高分子物の混合，および添加物質による 改質がある．たとえば，高分子物を結晶化させて耐薬 品性を向上させる方法があり，低圧法重合のポリエチ レンがその例である.ブロック法で得られるスチレン とブタジェンとの共重合物は, 普通の SBR と同じ単 量体組成のものでも，加工性が向上している.このほ か，耐熱性塩化ビニルの製造，わが国での ABS の製 造, 酸化防止剂または紫外線吸収剤の開発などがあ る.これら既存高分子物の改質によって得られた高分 子物は，母体となった高分子物の欠点を補なってはい るが，既存高分子物にかわって，はん用の樹脂となっ たものは，低圧法ポリエチレンと ABS だけである.

耐食有機材料注ライニング用, 塗料用㧍よび構造材 料用に分けられ，種々の天然抢よび合成高分子物質が 含まれる。これらを総括して表 1 に示す.

耐食有機材料の新しい施工法としては，水溶性塗料 の電着塗装およびショッププライマー塗装がある。電 着塗装は高分子電解質, たとえばアルキッド樹脂系の プレポリマの水溶液から高分子物を電着により塗装す る方法で, 引火性溶剤の使用量の少ないことと, ピン ホールの少ないこと执よ゙生産性の高いことなどの特 長がある.ショッププライマー塗装は，ヨーロッパの 造船業界を中心に発達した方法で, 鋼板の状態でさび 落しおよびプライマーの塗装を行ない，加工後のさび 落し面積を減らし，生産性の低い現地でのさび落し作 業を省略する方法である。

\section{1.あとがき}

化学装置に用いら机る耐食材料の最近の動向につい てその概略を述べた．化学工羓における操業の安定化 をはかるためには，化学的, 化学工学的, 機械工学的 または計測自動制御的技術に加えて，装置材料の防食 技術が特に重要な問題である，防食技術には，(1)適正 材料の使用，(2)インヒビタや電気防食法などによる環 境処理, (3)めっき, 溶射, 塗装, ライニングおよびク ラッディングなどによる環境しゃ断，(4)操業時におけ る防食管理などがある。これらのうち，適正な耐食材 料を使用することは, 最も積極的にして合理的な防食 技術である。すなわち，耐食材料の進歩は，直接化学 工業発展の基礎となるものであり，さらにこれら分野 の研究の進展を望むものである.

一方，耐食材料を使用する側においては，適確な耐 
食試験法により，使用環境条件に最も適応した材料を 選定使用することが必要である.

\section{文献}

（1）高村，第 12 回窝食防食討論会予稿集，(昭 40)，152.

（2）小若・ ほ加2 名, 第 58 回金属学会講演概要，(佋 41)，84

（3）寺前・門，第 13 回窥食防食討論会予稿篹，(昭 41)，247.

(4) E. Williams \& M.F. Komp, Corrosion, 21 (1965), 9.

(5) 特許公告, 昭 41-7923.

(6) Brit. Pat., 1,002,057 (1965).

(7) Corr. Technol., 12-9 (1965), 30.

（8）䇺岛，金属学会会報，5（环 41），188.

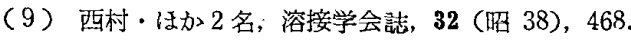

（10）洨辺，第 10 回窝食防食討諭会子稿集，(昭 38)，16.

（11）下田，防食技街，14（昭 40)，241.

(12) E. Herzog, Indust. Engng. Chem., 53-9 (1961), 56 A.

（13）中内・栂野，防食技術，14（昭 40)，10。

(14) C.M. Hudgins · 任汃 3 名，Corrosion, 22 (1966), 238.

（15）石冢·大西, 金属学会誌, 30 (昭 41)，846，852.

（16）湯川・はか 3 名，防食技術，15（昭 41），445.

(17) 植田・川村, 溶接学会誌, 36 (昭 42)，429.

（18）下田・は加 4 名，金属学会誌，31（昭 42），54

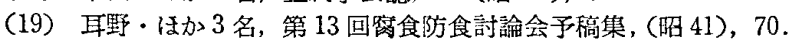

(20) 特詐公告, 昭 42-11135.

(21) 特竍公告, 明 41-1202.

（22）長谷川，金属材料，6-9（昭 41)，9.

（23）麻生，金您材料，6-9 (昭 41)，22。

（24）瓶野，金属材料，6-9 (昭 41)，18.

（25）堀川，金属村料，6-9 (昭 41)，28.

（26）特許公告, 昭 38-14006.

(27) L.R. Scharfstein, Corrosion, 21 (1965), 254.

(28) Czech Pat, 116815 (1965).

(29) 特部公告, 昭 42-6803.

(30) 特许公告, 昭 37-14458.

(31) N.D. Tomashov, Corrosion, 20 (1964), 7 t.

(32) 特訐公告, 昭 41-6442.

(33) 特許公告, 昭 41-5721.

(34) 特許公告, 昭 41-14283.

(35) H.J. Kirschning, Arch. Eisenhütt, 34 (1963), 269.

(36) E.A. Lizlovs, Corrosion, 22 (1966), 297.

(37) G.P. Tschernowa \& N.D. Tomashov, Z. Physik. Chem., 226 (1964), 136.

（38）原田・はか2 名, 金属学全誌, 29 (昭 40), 367.

(39) 特等公告, 昭 42-11138.

(40) N.D. Tomashov • はか 2 名, Corrosion, 20 (1964), 166 t.

（41）金子・はか 2 名，第 13 回窝食防食討論会予稿集，(昭 41)，223.

（42）渡辺 (正) - 渡辺 (寛), 機械学会論文集, 29-202（昭 38-6）, 1068.

(43) F.S. Lang, Corrosion, 18 (1962), 378t.

（44）高野·下平，金属学会誌，29（昭 40)，553.

（45）横田，第 11 回窝食防食討諭会予稿集，(昭 39)，15.

（46）高野・は汃3名，金属学会誌，28（昭 39），237.

（47）永吉・は汃 2 名, 第 13 回腐食防食討諭会予稿集，(昭 41)，66.

（48）水野，ケミカルエンシニャリング，11-9（昭 41），1.

（49）水野・は汃, 金属学会会報, 3 (昭 39), 622 .

(50) J.S. Armijo, Corrosion, 21 (1965), 235.

(51) 木村，ケミカルエンシニャリング, 11-9 (昭 41)，35.

（52）佐藤，金属学会誌，27 (昭 38), 134.

(53) H.R. Copson \& S.W. Dean, Corrosion, 21 (1965), 1.

(54) H. Coriou - 加 3 名, Corrosion, 22 (1966), 280.

（55）井上·土㫢, 金属学会誌, 27 (昭 38)，293.

(56) B.E. Hopkinson, ASME Paper, 62-WA-274, (19631-10).

（57）井上·土星，金属学会誌，26（昭 37），165.

(58) 特竍公告, 晒 40-29167.

(59) M.A. Streicher, Corrosion, 19 (1963), $272 \mathrm{t}$.

(60) H. Saimans - 任办 2 名, Corrosion, 22 (1966), 336.

(61) 特許公告, 昭 41-10607.

(62) E. Ward \& J.B. Maylor, Werks. Korr., 16 (1965), 382.
(63) J.S. Pat., 3 129,095 (1964).

(64) F.P.A. Robinson \& D.J. DuPlessis, Corrosion, 22 (1966), 117

(65) 特海公告, 昭 42-5523.

（66）宇都・は公》2 名, 金舁学会誌, 27 (昭 38 ), 18 .

（67）宇都・はか 2 名, 金楀学会誌, 28 (昭 39), 704.

（68）菅原・は汃 2 名, 金属学会誌, 30 (昭 41), 770.

（69）菅原・下平, 金属学会誌, 30 (昭 41), 775.

（70）田部，金属学全誌，28 (昭 39)，874。

（71）田部，金属学会誌，27 (昭 33)，337。

(72) 特許公告, 昭 39-22495.

(73) 特許公告, 昭 36-10054.

（74）大津，防食技術，12（昭 38），413.

(75) W. Lyner, Corrosion, 21 (1965), 125.

（76）田部，金属学会誌，30（昭 41)，237.

(77) H.E. Johnson \& J. Leja, Corrosion, 22 (1966), 178.

（78）村上·猪飼，第 13 回窝食防食討論会予稿集，(昭 41)，56.

（79）村上・ほか 2 名, 金属学会誌, 29 (昭 40), 1215.

(80) D.K. Fox, Mod. Casting, 42-12 (1962), 51.

(81) 特部公告, 昭 38-25006.

(82) U.S. Pat., 3252,793 (1966).

(83) A.W. Tracy, Chem. Engng., 69-1 (1962), 130.

(84) L. Piatti \& E. Fot, Werks. Korr., 1j (1964), 27.

(85) B. Upton, Corrosion, 13 (1963), $204 \mathrm{t}$.

（86）瑁山・保汃 2 名, 金属学会誌, 25 (昭 37)， 136.

(87) Fr. Pat., 1419862 (1965).

(88) A.W. Tracy, Chem. Engng., 69-2 (1962), 152.

(89) 特竍公告, 昭 38-4459.

(90) B.E. HopKinson, Corrosion, 20 (1964), sot.

(91) 特許公告, 昭 42-1364.

(92) R.W. Flourney, Mater. Prot., 3-11 (1964), 45.

(93) R.S. Dalrymple, Mater. Prot., 1-5 (1962), 36.

(94) J.F. Whiting, Mater. Prot,, 1-11 (1962), 36.

(95) E.T. Wanderer, Mater. Prot., 2-6 (1963), 54.

(96) NACE T-2M Report, Mater. Prot., 2-10 (1963), 101.

(97) D.B. Bird \& R.W. Flournoy, Mater. Prot., 3-11 (1964), 56.

（98）䯩野・仿汃2名，金属学会誌，26（昭 37)，297.

(99) W.H. Ailor \& F.M. Reinhart, Mater. Prot., 2-6 (1963), 30

（100）中村，柽金属，13 (昭 38)，237.

(101) D.O. Sprowls \& H.C. Rutemiller, Mater. Prot., 2-6 (1963), 62.

(102) F.M. Reinhart \&W.F. Gerhold, Corrosion, 18 (1962), $158 \mathrm{t}$.

(103) R.B. Niederberger • 化 2 名, Corrosion, 22 (1966), 68.

(104) S.J. Ketcham \& F.H. Haynie, Corrosion, 19 (1963), 242 t.

（105）谷·石川，㪕金属，15（昭 40）, 140.

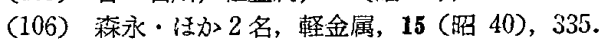

(107) W.M. Lovkovic·は加2名, Mater. Prot., 3-11 (1964), 16.

(108) I.G. Hohlstein \& E. Pelzel, Metall, 1s (1962), 764.

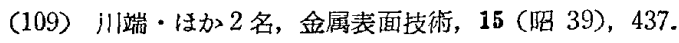

(110) 特新公告, 昭 39-56.

(111）特午公告, 昭 41-19521.

(112) K. Rüdinger, Werks. Korr., 16 (1965), 109.

(113）下瀬・蛣2 名, 防食技術, 14 (昭 40), 60.

(114) H. Zitter • は加 2 名, Werks. Korr., 16 (1965), 741.

(115）栗尾・は汃 3 名, 防食技術, 16 (昭 42)，107.

（116）下瀬・高村, 金渴学会誌，29（昭 40)，416.

（117）チタニウム愁話会，Zrの矢用化代関する研究報告書, (昭37).

（118）瀬川・は加 3 名，防食技術，13（昭 36）, 214.

（119）下瀬・森，防食技術，12（昭 38），460.

（120）木村·佐々木，金属学会会報，4（昭 40）,585.

（121）野由・活汃2名，防食技術，15（昭 41），289.

(122) 特許公告, 昭 37-7854.

（123）依田，金属学会会報，3（昭 39），415.

(124) D.L. Macleary, Corrosion, 18 (1962), 67t.

(125) D.L. Douglass, Corrosion, 19 (1963), $134 \mathrm{t}$. 